KONTINU: Jurnal Penelitian Didaktik Matematika

Vol: 2, No.2, Oktober 2018

\title{
KEMAMPUAN REPRESENTASI MATEMATIS SISWA PADA MATERI LINGKARAN BERDASAR GAYA BELAJAR HONEY MUMFROD
}

\author{
Indrayana Ika Sanjaya ${ }^{1)}$, Hevy Risqi Maharani' ${ }^{2)}$, Mochamad Abdul Basir ${ }^{3)}$ \\ Pendidikan Matematika, Universitas Islam Sultan Agung ${ }^{1,2), 3)}$ \\ indrayana.ika.s@gmail.com ${ }^{1)}$, hevyrisqi@unissula.ac.id²),abdulbasir@unissula.ac.id ${ }^{3)}$
}

\begin{abstract}
Abstrak. Representasi adalah bentuk interpretasi pemikiran siswa terhadap suatu masalah. Setiap siswa berbeda-beda dalam merepresentasikan pemikiran mereka dikarenakan setiap orang memiliki kemampuan otak yang berbeda-beda dalam menyerap, mengelola, dan menyampaikan informasi sehingga cara individu dalam belajarpun berbeda. Penelitian ini bertujuan untuk mengetahui klasifikasi gaya belajar Honey Mumfrod pada siswa kelas XI IPA 1 MAN 1 kota Semarang dan mendeskripsikan kemampuan representasi matematis siswa kelas XI IPA 1 MAN 1 kota Semarang dalam menyelesaikan soal pada materi lingkaran berdasar gaya belajar Honey Mumfrod pada siswa. Subjek penelitian ini adalah siswa kelas XI IPA 1 MAN 1 Kota Semarang. Hasil penelitian menunjukkan bahwa: siswa dengan tipe gaya belajar aktivis memiliki kemampuan representasi simbolik yang baik, sedangkan untuk kemampuan representasi verbal dan visual dalam kategori cukup. Siswa dengan tipe gaya belajar reflektor memiliki kemampuan representasi simbolik dan verbal yang baik, sedangkan untuk kemampuan representasi visual dalam kategori cukup. Siswa dengan tipe gaya belajar theoris memiliki kemampuan representasi visual, simbolik dan verbal yang baik. Siswa tipe gaya belajar pragmatis memiliki kemampuan representasi simbolik yang baik, sedangkan untuk kemampuan representasi verbal dan visual dalam kategori cukup. Namun, dalam aspek kemampuan representasi visual gaya belajar pragmatis lebih baik dibandingkan dengan gaya belajar aktivis.
\end{abstract}

Kata kunci: representasi matematis, gaya belajar, lingkaran

Abstract, Representation is a form of interpretation of students' thinking about a problem. Each student is different in representing their thoughts because each person has different brain abilities in absorbing, managing, and conveying information so that the ways in which individuals learn are different. This study purpose to determine the classification of Honey Mumfrod learning styles in students of class XI Science 1 MAN 1 city of Semarang and describe the mathematical representation ability of students of class XI IPA 1 MAN 1 city of Semarang in solving questions on circular material based on the learning style of Honey Mumfrod in students. The subjects of this study were students of class XI IPA 1 MAN 1 Semarang City. The results showed that: students with the type of activist learning style had good symbolic representation abilities, while for the ability of verbal and visual representations in the sufficient category. Students with reflector learning style types have good ability of symbolic and verbal representation, while for visual representation abilities are in sufficient categories. Students with the type of theoretic learning style have good ability of visual, symbolic and verbal representation. Students with pragmatic learning styles have good symbolic representation abilities, while for the ability of verbal and visual representations in the sufficient category. However, in terms of the ability of visual representation the pragmatic learning style is better than the activist learning style.

Keywords: mathematical representation, learning style, circle 
KONTINU: Jurnal Penelitian Didaktik Matematika

Vol: 2, No.2, Oktober 2018

\section{PENDAHULUAN}

Salah satu bidang studi yang berperan penting dalam kehidupan adalah matematika, peranan matematika dalam dunia pendidikan adalah sebagai salah satu sumber ilmu dari ilmu yang lain. Karena dianggap penting dan wajib peranannya maka matematika diajarkan di semua jenjang pendidikan. Kline (dalam Husain, 2016) menyatakan matematika itu bukanlah pengetahuan menyendiri yang dapat sempurna karena dirinya sendiri, tetapi adanya matematika itu terutama untuk membantu manusia dalam memahami dan menguasai permasalahan sosial, ekonomi, dan alam. Sinaga ( 2016) menyatakan matematika merupakan salah satu bidang ilmu yang dapat meningkatkan kemampuan seseorang dalam berfikir secara logis, rasionalis, kritis, cermat, efektif dan efesien namun untuk mencapai hal tersebut dibutuhkan pemahaman dan kompetensi matematika yang baik.

NCTM (2000) menyatakan terdapat lima standar yang mendeskripsikan keterkaitan pemahaman matematis dan kompetensi matematika yang hendaknya siswa ketahui dan dilakukan. Pemahaman, pengetahuan dan ketrampilan yang perlu dimiliki siswa tercakup dalam standar prosesyaitu: kemampuan pemecahan masalah, penalaran, komunikasi, koneksi, dan representasi.Dalam proses pembelajaran matematika, kemampuan representasi adalah salah satu hal yang sangat penting dalam menunjang keberhasilan tercapainya proses pembelajaran. Basir \& Maharani (2016) menyatakan orientasi kurikulum menekankan proses pembelajaran dengan tidak melupakan tujuan pembelajaran matematika yaitu pencapaian hasil belajar di sekolah untuk meningkatkan ketajaman penalaran siswa dalam memecahkan masalah dalam kehidupan sehari-hari,serta meningkatkan kemampuan berpikir dalam menggunakan angka dan simbol matematika.

Representasi adalah bentuk interpretasi pemikiran siswa terhadap suatu masalah, yang digunakan sebagai alat bantu untuk menemukan solusi dari masalah tersebut. Bentuk interpretasi siswa dapat berupa kata-kata atau verbal, tulisan, gambar, tabel, grafik, benda konkrit, simbol matematika dan lain-lain, (Sabirin, 2014). Representasi terbagi menjadi dua, yaitu representasi eksternal dan representasi internal (Adu-Gyamfi, 2003). Hiebert dan Chorpenter menyatakan representasi internal merupakan proses berfikir tentang ide-ide matematika yang memungkinkan pikiran seseorang bekerja atas dasar ide tersebut. Representasi internal sulit diamati secara langsung karena merupakan aktivitas seseorang didalam pemikirannya (minds-on). Sehingga representasi internaldiamati melaluirepresentasi eksternalnya. Sedangkan Janvier menjelaskan bahwa 
KONTINU: Jurnal Penelitian Didaktik Matematika

Vol: 2, No.2, Oktober 2018

representasi eksternal menunjukkan wujud secara fisik dari suatu ide matematis (Kartini, 2009). Representasi eksternal meliputi representasi verbal (tertulis), representasi visual (piktorial dan skematik), dan representasi simbolik (persamaan yang menunjukkan hubungan dua atau lebih kuantitas). Kemampuan representasi matematis dapat disimpulkan kemampuan siswa menggunakan ungkapanungkapan dari ide matematika yang ditampilkan siswa sebagai model atau cara menyelesaikan masalah yang sedang dihadapinya sebagai hasil dari interpretasi pikirannya.

Materi lingkaran merupakan salah satu materi yang dianggap sulit, penjelasan Ibu Puji guru pengampu mata pelajaran matematika MAN 1 Kota Semarang menyatakan dianggap materi lingkaran sulit karena materi lingkaran tidak memiliki materi pra syarat. Pada ujian nasional (UN) banyak siswa yang belum bisa menyerap materi dengan sempurna, pada tingkat provinsi persentase analisis butir soal siswa pada materi lingkaran pokok bahasan garis singgung hanya 38,12\%. Hasil wawancara dengan Puji Lestari S.Pd guru Madrasah Aliyah Negeri 1 Semarang menjelaskan kemampuan siswa merepresentasikan materi masih sangat lemah. Pada aspek representasi visual, siswa kurang mampu memahami gambar dengan tepat dalam menyelesaikan suatu permasalahan. Pada aspek representasi simbolik, siswa masih sering melakukan kesalahan dalam operasi hitung bilangan dan pada aspek representasi verbal siswa kurang mampu menyelesaikan permasalahan soal dengan langkah-langkah dan menyimpulkan secara tepat.

Muawanah (2015) menyatakan sebanyak 37\% siswa masih kesulitan untuk mengubah data yang diketahui dalam soal kedalam simbol matematika. Nikmah (2017) perbedaaan setiap siswa dalam merepresentasikan pemikiran mereka disebabkan setiap orang memiliki kemampuan otak yang berbeda-beda dalam menyerap, mengelola, dan menyampaikan informasi sehingga cara individu dalam belajarpun berbeda. Cara belajar itu dikenal dengan istilah gaya belajar. Dunn Dunn (dalam Cavas, 2010) mendefinisikan gaya belajar sebagai cara seseorang untuk berkonsentrasi, memproses, dan menguasai informasi-informasi baru pada saat pembelajaran.Lemahnya kemampuan representasi matematis siswa di pengaruhi berbagai faktor, Salah satu faktor adalah gaya belajar. Qomarudin (2018) pembelajaran yang saat ini berjalan di sebagian besar sekolah adalah seorang guru menyampaikan pembelajaran menggunakan strategi pembelajaran yang sudah dikuasai tanpa memahami bahwa setiap siswa ataupun sekelompok siswa dalam kelas memiliki kecenderungan gaya belajar yang berbeda-beda. Menurut Hudiono (2010), Keterbatasan pengetahuan guru dan kebiasaan belajar siswa di kelas dengan cara 
KONTINU: Jurnal Penelitian Didaktik Matematika

Vol: 2, No.2, Oktober 2018

konvensional belum memungkinkan untuk menumbuhkan atau mengembangkan daya representasi siswa secaraoptimal.

Representasi yang muncul dari siswa merupakan ungkapan- ungkapan dari gagasan atau ide-ide matematika yang disampaikan siswa dalam upayanya untuk mencari suatu solusi dari masalah yang sedang dihadapinya (NCTM, 2000). Efendi (2012) menyatakan kemampuan representasi matematis diperlukan siswa untuk menemukan dan membuat suatu alat atau cara berpikir dalam mengkomunikasikan gagasan matematis dari sifatnya abstrak menuju konkrit, sehingga lebih mudah untuk dipahami. Cara siswa berfikir dan mengkomunikasikan gagasan matematis inilah yang kita lihat dari gaya belajar, sehingga kemampuan representasi siswa dapat kita lihat dari gaya belajar siswa itu sendiri. Salah satu gaya belajar yang banyak dilakukan siswa adalah gaya belajar Honey Mumfrod. Gaya belajar ini mengajak siswa untuk memiliki pengalaman yang nyata dalam proses belajar.

Gaya belajar Honey Mumfrod berkaitan dengan sikap, personaliti dan ciri-ciri seorang individu tersebut. Oleh karena itu, sikap dan tingkah laku akan menentukan jenis gaya pembelajar seorang siswa. Gaya belajar Honey Mumfrod ini bersifat fleksibel sehingga siswa tidak perlu memulai dari concrete experience(merespon pembelajaran berkaitan dengan pengalamannya) siswa dapat memulai dari Reflektive Observation (menganalisis apa yang dia terima), Abstrak Conceptualization (merespon pembelajaran berdasarkan teori yang telah dibaca), atau Active Experimentation (menyenangi pendekatan praktik). Hal ini karena prior knowledge(pengetahuan awal) setiap orang berbeda-beda sehingga siswa dapat memulai dari karakteristik gaya belajar sesuai dirinya sendiri.

Honey \& Mumfrod membagi sikap dan tingkah laku dalam 4 katagori yaitu: aktifis, reflektif, teoris dan pragmatis. Identifikasi gaya belajar siswa oleh guru merupakan hal yang sangat penting. Hal ini dikarenakan bahwa siswa yang mengetahui tipe gaya belajar mereka akan menyesuaikan diri dengan pembelajaran di kelas agar sukses dalam belajar (dalam Yahaya, 2003). Berdasarkan latar belakang tersebut peneliti tertarik untuk melakukan analisis terhadap kemampuan representasi matematis siswa dalam menyelesaikan masalah matematika pada materi lingkaran berdasar gaya belajar Honey Mumfrod. Sehingga, tujuan penelitian ini adalah untuk mengetahui klasifikasi gaya belajar Honey Mumfrod pada siswa kelas XI IPA 1 MAN 1 kota Semarang dan mendiskripsikan kemampuan representasi matematis siswa kelas XI IPA 1 MAN 1 kota Semarang dalam menyelesaikan soal pada materi lingkaran berdasar gaya belajar Honey Mumfrod pada siswa. 
KONTINU: Jurnal Penelitian Didaktik Matematika

Vol: 2, No.2, Oktober 2018

\section{METODE PENELITIAN}

Pendekatan penelitian ini menggunakan pendekatan penelitian kualitatif, dengan jenis penelitian yang digunakan adalah penelitian diskriptif kualitatif, data yang dihasilkan berupa kata tertulis sebagai data penalaran dan pemecahan masalah dan lisan untuk mendeskripsikan kemampuan siswa dalam menelaah dan memecahkan masalah atas dasar data yang diperoleh dari lapangan. Penelitian ini dilakukan dengan cara memberikan angket gaya belajar Honey Mumfrod kepada siswa, melakukan tes kemampuan representasi matematis, serta melakukan wawancara.. Fokus pada penelitian ini yaitu menganalisis kemampuan representasi matematis pada setiap tipe karakteristik gaya belajar siswa.Analisis kemampuan representasi matematis dilihat dari hasil pekerjaan siswa dalam menyelesaikan soal-soal tes kemampuan representasi matematis. Penelitian ini dilaksanakan di sekolahMAN 1 kota Semarang pada bulan Maret 2018 sampai bulan April 2018. Sumber data pada penelitian ini yaitu kelas XI IPA 1 MAN 1 kota Semarang tahun ajaran 2017/2018.

Sumber data penelitian ini diambil dengan cara purposive sampling (sampel tujuan) yang dipilih berdasarkan tujuan yang hendak dicapaiyaitu mengetahui kemampuan representasi matematis berdasar gaya belajar Honey Mumfrod pada siswa. Dari siswa kelas XI IPA 1 MAN 1 kota Semarang diambil 8 orang siswa sebagai subjek penelitian dan setiap tipe karakteristik gaya belajar Honey Mumfrod diwakili oleh 2 siswa ditentukan setelah diperoleh hasil pada angket gaya belajar Honey Mumfrod. Metode pengambilan data yang digunakan ada 3: metode angket, metode tes dan metode wawancara. Adapun metode angket dengan menggunakan angket gaya belajar Honey Mumfrod, metode tes dengan menggunakan tes kemampuan representasi matematis sebanyak tiga butir soal sebagai berikut:

1). tentukan kedudukan garis $g: x-y=2$ terhadap lingkaran $L: x^{2}+y^{2}=16$ dan gambarkan sketsa lingkarannya!

2). tentukan kedudukan lingkaran $K: x^{2}+y^{2}=16$ terhadap lingkaran $L: x^{2}+y^{2}-$ $2 x+4 y+4=0$ dan gambarkan sketsa lingkarannya!

3). Tentukan persamaan garis singgung lingkaran $(x-2)^{2}+(y-7)^{2}=169$ di titik $(7,-5)$ dan gambarkan sketsa lingkaranya!

Analisis data pada penelitian ini melalui tiga tahapan antara lain Reduksi Data, Penyajian Data, Conclution Drawing / Verification. Langkah-langkah dalam penelitian ini yaitu: melihat latar belakang subjek, mempersiapkan instrumen, validasi instrumen, pengisian angket gaya belajar Honey Mumfrod, klasifikasi tipe gaya belajar Honey Mumfrod, Pelaksanaan tes kemampuan representasi matematis, pelaksanaan wawancara, 
KONTINU: Jurnal Penelitian Didaktik Matematika

Vol: 2, No.2, Oktober 2018

analisis data, pendiskripsian kemampuan representasi matematis pada materi lingkaran berdasar gaya belajar Honey Mumfrod, dan penarikan kesimpulan.

\section{HASIL PENELITIAN DAN PEMBAHASAN}

Hasil dari penelitian yang dilakukan di MAN 1 Semarang ini meliputi, hasil angket gaya belajar Honey Mumfrod dan hasil tes kemampuan representasi matematis. Data skor angket gaya belajar Honey Mumfrod dikelompokkan menjadi 4 tipe gaya belajar yaitu aktivis, reflektor, theoris dan pragmatis.Penggolongan gaya belajar siswa ditentukan dengan pernyataan gaya belajar yang paling banyak dipilih. Hasil angket penggolongan gaya belajar siswa pada penelitian ini dapat dilihat pada tabel 1 .

\begin{tabular}{cccc}
\hline No & Gaya Belajar & Jumlah Siswa & Persentase \\
\hline 1 & Aktivis & 2 & $5,56 \%$ \\
\hline 2 & Reflektor & 18 & $50,00 \%$ \\
\hline 3 & Theoris & 10 & $27,77 \%$ \\
\hline 4 & Pragmatis & 6 & $16,67 \%$ \\
\hline & Jumlah & 36 & $100,00 \%$ \\
\hline
\end{tabular}

Tabel 1. Hasil Penggolongan Gaya Belajar Siswa

Hasil tes kemampuan representasi matematis siswa dikatagorikan menjadi 3 katagori yaitu baik, cukup, dan kurang. Aspek kemampuan representasi visual tipe gaya belajar theoris dalam katagori baik sedangkan untuk tipe gaya belajar lainnya dalam katagori cukup. Dalam aspek kemampuan representasi simbolik semua tipe gaya belajar dalam katagori baik. Sedangkan dalam aspek kemampuan representasi verbal tipe gaya belajar theoris dan tipe gaya belajar reflektor dalam katagori baik sedangkan untuk tipe gaya belajar aktivis dan pragmatis dalam katagori cukup.

Berdasarkan pengisian angket gaya belajar Honey Mumfrod kebanyakan siswa dikelas XI IPA 1 MAN 1 Kota Semarang lebih suka pembelajaran dengan cara diskusi, meneliti, mengkaji ulang dan kerja kelompok karakteristik siwa ini adalah tipe gaya belajar reflektor (Lockitt, 1997) sehingga kebanyakan siswa di kelas XI IPA 1 MAN 1 Kota Semarang memiliki gaya belajar reflektor, sedangkan hanya satu sampai dua orang saja yang gemar belajar dengan cara menemukan ide, bertindak cepat, dan memiliki jiwa pemimpin karakteristik siswa ini adalah tipe gaya belajar aktivis(Lockitt, 1997).

Siswa yang memiliki gaya belajar aktivis adalah mereka yang gemar melakukan penemuan baru. Sehingga, tipe gaya belajar aktivis memiliki kemampuan representasi yang baik dalam aspek representasi simbolik, sedangkan untuk aspek representasi visual dan verbal dalam katagori cukup. Berdasarkan indikator kemampuan representasi matematis menurut NCTM (2000) yaitu: (1) menggunakan representasi untuk memodelkan dan 
KONTINU: Jurnal Penelitian Didaktik Matematika

Vol: 2, No.2, Oktober 2018

menafsirkan masalah matematika secara fisik. (2) membuat dan menggunakan representasi untuk mengatur, merekam dan mengkomunikasikan ide-ide matematika. (3) memilih, menerapkan dan menterjemahkan suatu representasi matematika untuk menyelesaikan masalah matematika. Siswa tipe gaya belajar aktivis mampu memenuhi indikator dalam aspek simbolik yaitu membuat dan menggunakan representasi untuk mengatur, merekam dan mengkomunikasikan ide-ide matematika. Siswa dengan tipe gaya belajar aktivis mampu membuat persamaan matematik baru dan menganalisis/menemukan titik pusat dan jari-jari pada persamaan lingkaran. Namun tipe gaya belajar aktivis belum mampu memenuhi indikator dalam aspek kemampuan verbal dan visual. Ini dibuktikan dengan kesalahan siswa dalam menggambar sketsa dari permasalahan yang diberikan. Serta tipe gaya belajar aktivis belum mampu menyimpulkan dengan tepat hasil penyelesaian yang telah dikerjakan.

Siswa yang memiliki gaya belajar reflektor adalah mereka yang berhati-hati dan teliti sebelum melakukan sesuatu. Sehingga, tipe gaya belajar reflektor dalam kemampuan merepresentasikan sesuatu unggul dalam aspek representasi simbolik dan aspek representasi verbal. Berdasarkan indikator kemampuan representasi matematis menurut NCTM (2000) yaitu: (1) menggunakan representasi untuk memodelkan dan menafsirkan masalah matematika secara fisik. (2) membuat dan menggunakan representasi untuk mengatur, merekam dan mengkomunikasikan ide-ide matematika. (3) memilih, menerapkan dan menterjemahkan suatu representasi matematika untuk menyelesaikan masalah matematika. Tipe gaya belajar reflektor mampu memenuhi indikator dalam aspek simbolik dan verbal. Siswa dengan tipe gaya belajar reflektor mampu menganalisis/membuat persamaan baru dari representasi yang diberikan dan mampu menentukan langkah-langkah penyelesaian dari masalah yang diberikan serta menyimpulkan hasil penyelesaian dengan kata-kata. Namun siswa dengan tipe gaya belajar reflektor belum mampu memenuhi indikator dalam aspek kemampuan visual ini dibuktikan dengan kesalahan siswa dalam membuat sketsa garis singgung lingkaran.

Siswa yang memiliki gaya belajar theoris adalah mereka yang mengembalikan sesuatu pada theori sebelum melakukan tindakan. Sehingga, tipe gaya belajar theoris dalam kemampuan merepresentasikan sesuatu unggul dalam 3 aspek representasi yaitu: aspek representasi visual, aspek representasi simbolik dan aspek representasi verbal. Berdasarkan indikator kemampuan representasi matematis menurut NCTM (2000) yaitu: (1) menggunakan representasi untuk memodelkan dan menafsirkan masalah matematika secara fisik. (2) membuat dan menggunakan representasi untuk mengatur, merekam dan mengkomunikasikan ide-ide matematika. (3) memilih, menerapkan dan menterjemahkan 
KONTINU: Jurnal Penelitian Didaktik Matematika

Vol: 2, No.2, Oktober 2018

suatu representasi matematika untuk menyelesaikan masalah matematika. Tipe gaya belajar theoris mampu memenuhi indikator dalam aspek visual, simbolik dan verbal. Siswa dengan tipe gaya belajar teoris mampu membuat persamaan matematik baru dan menganalisis/menemukan titik pusat dan jari-jari pada persamaan lingkaran. Siwa dengan tipe theoris juga mampu menentukan langkah-langkah penyelesaian dan menyimpulkannya dengan kata-kata Namun tipe gaya belajar theoris dalam aspek visual dalam menggambarkan kedudukan lingkaran dengan garis atau lingkaran lain ada sedikit kesalahan.

Siswa yang memiliki tipe gaya belajar pragmatis adalah mereka yang gemar belajar secara praktis dan senang menyelesaikan masalah dengan ide-ide praktis. Sehingga, tipe gaya belajar pragmatis dalam kemampuan merepresentasikan sesuatu unggul dalam aspek representasi simbolik. Berdasarkan indikator kemampuan representasi matematis menurut NCTM (2000) yaitu: (1) menggunakan representasi untuk memodelkan dan menafsirkan masalah matematika secara fisik. (2) membuat dan menggunakan representasi untuk mengatur, merekam dan mengkomunikasikan ide-ide matematika. (3) memilih, menerapkan dan menterjemahkan suatu representasi matematika untuk menyelesaikan masalah matematika. Tipe gaya belajar pragmatis memenuhi indikator dalam aspek simbolik, tetapi tipe gaya pragmatis belum mampu memenuhi indikator dalam aspek visual dan verbal. Siswa dengan tipe gaya belajar pragmatis mampu membuat persamaan matematik baru dan menganalisis/menemukan titik pusat dan jari-jari pada persamaan lingkaran. Namun tipe gaya belajar pragmatis dalam aspek kemampuan verbal masih kurang. Ini dibuktikan tipe gaya belajar pragmatis belum mampu menyimpulkan dengan tepat hasil penyelesaian yang telah dikerjakan. Dalam aspek visual tipe gaya belajar pragmatis mampu menggambarkan kedudukan lingkaran dengan garis atau lingkaran lain tetapi belum tepat. Tipe gaya belajar aktivis dan pragmatis sama-sama dapat memenuhi indikator aspek kemampuan simbolik dan belum mampu memenuhi indikator aspek kemampuan visual dan verbal. Dalam aspek kemampuan visual tipe gaya belajar pragmatis lebih baik dari pada tipe gaya belajar aktivis. Tipe gaya belajar pragmatis mampu menggambarkan sketsa garis singgung lingkaran dengan baik. Perbedaan hasil representasi visual antara gaya belajar aktivis dan pragmatis dapat dilihat pada gambar 1 dan gambar 2 . Tipe gaya belajar aktivis menggambarkan sketsa garis singgung lingkaran memotong pada lingkarannya. Sedangkan untuk tipe gaya belajar pragmatis menggambarkan sketsa garis singgung lingkaran menyinggung lingkarannya meskipun titik singgungnya belum tepat. 
KONTINU: Jurnal Penelitian Didaktik Matematika

Vol: 2, No.2, Oktober 2018

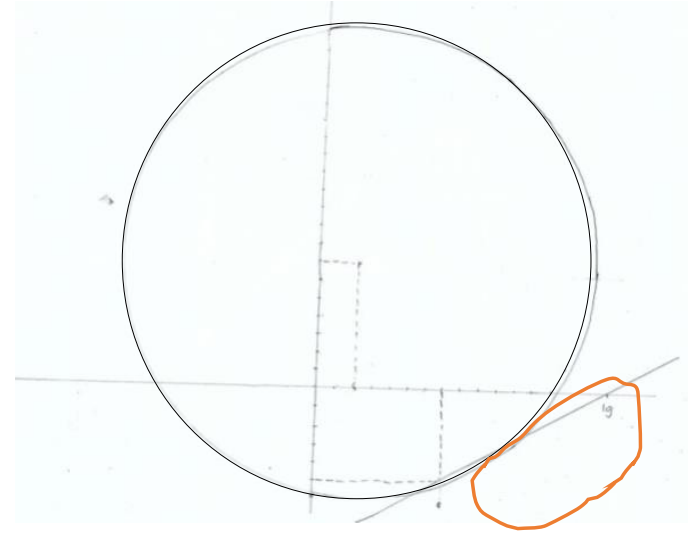

Gambar 1. Hasil Tes kemampuan representasi matematis siswa tipe gaya belajar aktivis

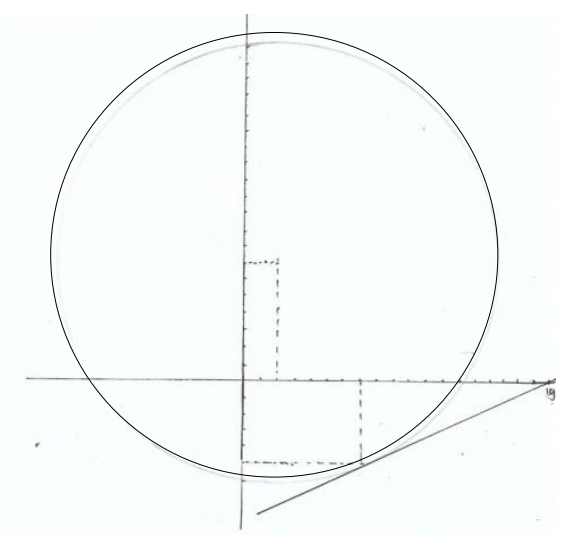

Gambar 2. hasil tes kemampuan representasi matematis siswa tipe gaya belajarpragmatis

Kemampuan representasi matematis setiap gaya belajar Honey Mumfrod berbeda-beda. Perbedaan kemampuan representasi matematis pada masing-masing tipe gaya belajar Honey Mumfrod dapat dilihat pada tabel 2.

\begin{tabular}{clll}
\hline & \multicolumn{2}{c}{ Indikator kemampuan representasi matematis } \\
\cline { 2 - 4 } & Menggunakan & Membuat dan & Memilih, menerapkan \\
& representasi untuk & menggunakan & dan menterjemahkan \\
Gaya & memodelkan dan & representasi untuk & suatu representasi \\
belajar & menafsirkan masalah & mengatur, merekam & matematika untuk \\
& matematika secara fisik & dan & menyelesaikan \\
& (Visual) & mengkomunikasikan & masalah matematika \\
& & ide-ide matematika & (Verbal) \\
& & (Simbolik) & \\
\hline
\end{tabular}




\begin{tabular}{|c|c|c|c|}
\hline$\frac{\stackrel{n}{Z}}{\frac{\pi}{2}}$ & $\begin{array}{l}\text { Mampu menggambarkan } \\
\text { sketsa kedudukan } \\
\text { lingkaran dengan } \\
\text { garis/dengan lingkaran } \\
\text { lain, namun hanya } \\
\text { sedikit gambar yang } \\
\text { benar yaitu } \\
\text { menggambarkan } \\
\text { lingkaran dengan pusat } \\
(0,0) \text { dan belum mampu } \\
\text { dengan tepat } \\
\text { menggambarkan sketsa } \\
\text { garis singgung }\end{array}$ & $\begin{array}{l}\text { Mampu menemukan } \\
\text { bentuk persamaan baru } \\
\text { dari persamaan garis. } \\
\text { Serta mampu } \\
\text { menganalisis titik } \\
\text { pusat dan jari-jari dari } \\
\text { persamaan lingkaran } \\
\text { yang diketahui. }\end{array}$ & $\begin{array}{l}\text { Mampu menentukan } \\
\text { penyelesaian masalah } \\
\text { tetapi tidak dapat } \\
\text { menyimpulkan dengan } \\
\text { benar pada kedudukan } \\
\text { dua lingkaran. }\end{array}$ \\
\hline 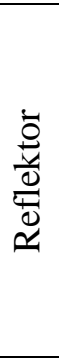 & $\begin{array}{l}\text { Mampu menggambarkan } \\
\text { sketsa kedudukan } \\
\text { lingkaran dengan } \\
\text { garis/dengan lingkaran } \\
\text { lain, namun kurang } \\
\text { lengkap dan benar dalam } \\
\text { menggambarkan sketsa } \\
\text { garis singgung }\end{array}$ & $\begin{array}{l}\text { Mampu menganalisis / } \\
\text { menemukan } \\
\text { persaamaan baru pada } \\
\text { persamaan lingkaran } \\
\text { seperti menentukan } \\
\text { titik pusat lingkaran } \\
\text { dengan benar. }\end{array}$ & $\begin{array}{l}\text { Mampu menentukan } \\
\text { penyelesaian masalah } \\
\text { dan dapat } \\
\text { menyimpulkan dengan } \\
\text { benar dari } \\
\text { penyelesaian yang } \\
\text { telah dilakukan. }\end{array}$ \\
\hline 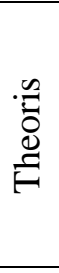 & $\begin{array}{l}\text { Mampu menggambarkan } \\
\text { sketsa kedudukan } \\
\text { lingkaran dengan } \\
\text { garis/dengan lingkaran } \\
\text { lain dengan benar }\end{array}$ & $\begin{array}{l}\text { Mampu menganalisis / } \\
\text { menemukan } \\
\text { persaamaan baru pada } \\
\text { persamaan lingkaran } \\
\text { dengan benar dan } \\
\text { lengkap }\end{array}$ & $\begin{array}{l}\text { Mampu menentukan } \\
\text { penyelesaian masalah } \\
\text { dan dapat } \\
\text { menyimpulkan dengan } \\
\text { benar }\end{array}$ \\
\hline 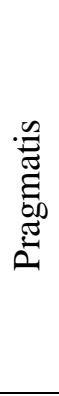 & $\begin{array}{l}\text { Mampu menggambarkan } \\
\text { sketsa kedudukan } \\
\text { lingkaran dengan garis/ } \\
\text { lingkaran lain, namun } \\
\text { kurang lengkap dan } \\
\text { benar dalam } \\
\text { mengambarkan sketsa } \\
\text { lingkaran yang berpusat } \\
\text { (a,b) }\end{array}$ & $\begin{array}{l}\text { Mampu menganalisis / } \\
\text { menemukan } \\
\text { persaamaan baru dari } \\
\text { persamaan garis dan } \\
\text { mampu menentukan } \\
\text { titik pusat/titik potong } \\
\text { dari persamaan } \\
\text { lingkaran. }\end{array}$ & $\begin{array}{l}\text { Mampu menentukan } \\
\text { penyelesaian masalah } \\
\text { tetapi tidak dapat } \\
\text { menyimpulkan dengan } \\
\text { benar hasil sketsa } \\
\text { gambar yang telah } \\
\text { dibuat. }\end{array}$ \\
\hline
\end{tabular}

Tabel 2. Perbedaan kemampuan representasi matematis pada masing-masing tipe gaya belajar Honey Mumfrod

Kemampuan representasi matematis setiap gaya belajar Honey Mumfrod berbedabeda.Siswa yang memiliki tipe gaya belajar aktivis menyukai cara belajar melibatkan pengalaman dan masalah baru.Aplikasi dalam proses belajar dan mengajar setelah mengetahui gaya belajar siswa guru bisa melakukan kegiatan pembelajaran Seperti penemuan untuk gaya belajar aktivis. Guru dapat memberikan soal matematis tentang menggambar/membuat diagram serta menuliskan kesimpulan dari pekerjaan siswa sehingga kemampuan representasi dalam aspek visual dan verbal lebih baik. Untuk siwa yang memiliki tipegaya belajar reflektor 
KONTINU: Jurnal Penelitian Didaktik Matematika

Vol: 2, No.2, Oktober 2018

menyukai pembelajaran yang sistematis.Aplikasi dalam proses belajar dan mengajar setelah mengetahui gaya belajar siswa guru bisa melakukan kegiatan pembelajaran melalui pengamatan. Guru dalam proses belajar mengajar dapat memberikan langkah-langkah penyelesaian untuk siswa agar lebih mudah merepresentasikan sesuatu. Contohnya seperti langkah-langkah menggambarkan kedudukan garis terhadap lingkaran sehingga kemampuan representasi visual lebih baik.

Siswa dengan tipegaya belajar Theorismenyukai pembelajaran yang menggunakan kemahiran dan pengetahuan untuk menyelesaikan suatu tugas, tipe gaya belajar theoris cenderung perfeksionis.Aplikasi dalam proses belajar dan mengajar setelah mengetahui gaya belajar siswa guru bisa melakukan kegiatan pembelajaranmenjelaskan teori-teori. Kemampuan representasi yang dimiliki tipe gaya belajar theoris sudah baik sehingga guru dapat memberikan soal-soal pengayaan supaya kemampuan dalam merepresentasikan baik.Sedangkan untuk siswa yang memiliki tipe gaya belajar pragmatis menyukai pembelajaran yang dapat dipraktikan.Aplikasi dalam proses belajar dan mengajar setelah mengetahui gaya belajar siswa guru bisa melakukan kegiatan pembelajaran menggunakan aktivitas pemecahan masalah atau diskusi. Guru dapat memberikan tugas kelompok dan memberi soal matematis yang berupa menggambarkan/ membuat grafik serta mengambil kesimpulan dari penyelesaian masalah yang telah dilakukan.

\section{PENUTUP}

Berdasarkan hasil angket gaya belajar Honey Mumfrod dan tes kemampuan representasi materi lingkaran berdasar gaya belajar Honey Mumfrod, diperoleh simpulan sebagai berikut: gaya belajar siswa kelas XI IPA 1 MAN 1 Kota Semarang dibagi menjadi 4 klasifikasi gaya belajar Honey Munfrod, sebanyak 5,56\% siswa memiliki gaya belajar aktivis; 50,00\% siswa memiliki gaya belajar reflektor; $27,77 \%$ siswa memiliki gaya belajar theoris dan $16,67 \%$ siswa memiliki gaya belajar pragmatis.

Adapun hasil analisis kemampuan representasi matematis siswa berdasar gaya belajar Honey Mumfrod sebagai berikut:Kemampuan representasi matematis siswa tipe gaya belajar aktivis yaitu siswa mampu merepresentasikan dengan baik representasi simbolik, sedangkan untuk representasi verbal dan visual dalam kategori cukup. Namun, dalam aspek representasi visual gaya belajar aktivis masih sangat lemah dibandingkan 
KONTINU: Jurnal Penelitian Didaktik Matematika

Vol: 2, No.2, Oktober 2018

dengan gaya belajar pragmatis.Kemampuan representasi matematis siswa tipe gaya belajar reflektor yaitu siswa mampu merepresentasikan dengan baik representasi simbolik dan verbal, sedangkan untuk representasi visual dalam kategori cukup.Kemampuan representasi matematis siswa tipe gaya belajar theoris yaitu siswa mampu merepresentasikan dengan baik representasi visual, representasi simbolik dan representasi verbal. Kemampuan representasi matematis siswa tipe gaya belajar pragmatis yaitu siswa mampu merepresentasikan dengan baik representasi simbolik, sedangkan untuk kemampuan representasi verbal dan visual dalam kategori cukup. Namun, dalam aspek kemampuan representasi visual gaya belajar pragmatis lebih baik dibandingkan dengan gaya belajar aktivis.

Berdasarkan hasil penelitian yang telah peneliti lakukan, maka guru disarankan untuk tipe gaya belajar aktivis melakukan kegiatan pembelajaran seperti penemuan, untuk gaya belajar reflektor melakukan kegiatan pembelajaran melalui pengamatan, untuk gaya belajar theoris melakukan kegiatan pembelajaran menjelaskan teori-teori, dan untuk gaya belajar pragmatis melakukan kegiatan pembelajaran menggunakan aktivitas pemecahan masalah atau diskusi. Kemudian Perlu adanya penelitian lanjutan mengenai faktor-faktor yang menyebabkan kemampuan representasi pada gaya belajar Honey Mumfrod berbedabeda sehingga dapat menyempurnakan penelitian ini dengan baik.

\section{DAFTAR PUSTAKA}

Adu-Gyamfi, K. (2003). External multiple representations in mathematics teaching. North Carolina State University.

Cavas, B. (2010). A Study On Pre-Service, Class, And Mathematic Teacher's Learning In Turkey. Science Education International Journal. 21 (1),47-61.

Effendi, L. A. (2012). Pembelajaran matematika dengan metode penemuan terbimbing untuk meningkatkan kemampuan representasi dan pemecahan masalah matematis siswa SMP. Jurnal Penelitian Pendidikan, 13(2).

Hudiono, B. (2012). Peran pembelajaran diskursus multi representasi terhadap pengembangan kemampuan matematika dan daya representasi pada siswa SLTP. Jurnal Cakrawala Kependidikan, 8(2),101-110.

Husain, F. P. (2016). Faktor-faktor Penyebab Kecemasan Matematika Pada Siswa Kelas V SD Inpres Mannuruki II Makasar [Skripsi]. Makasar (ID): Universitas Negeri Makassar.

Kartini, K. (2009). Peranan Representasi Dalam Pembelajaran Matematika. prosiding In Seminar Nasional Matematika dan Pendidikan Matematika 2009. Jurusan 
KONTINU: Jurnal Penelitian Didaktik Matematika

Vol: 2, No.2, Oktober 2018

Pendidikan Matematika FMIPA UNY.(361-371).

Lockitt, B. (1997). Learning Styles: Into the Future. Further Education Development Agency, Publications Dept., Mendip Centre, Blagdon, Bristol.

Muawanah, M. (2015). Analisis Kesalahan Siswa Dalam Menyelesaikan Soal Berdasarkan Prosedur Newman Pada Materi Lingkaran Di Smp Islam Sultan Agung 01 Semarang [Skripsi]. Semarang (ID):Universitas Islam Sultan Agung.

NCTM. (2000). Principles and Standards for School Mathematics. United States of America : The National Council of Teachers of Mathematics, Inc.

Nikmah, N. (2017). Analisis Kemampuan Representasi Matematis Siswa Kelas X MA Shalatiyah Bitin Ditinjau dari Gaya Belajar pada Materi Dimensi Tiga Tahun Pelajaran 2016/2017 [Skripsi]. Banjarmasin:UIN Antasari.

Qomarudin, M., Mustafa, M., \& Basir, M. A. (2018). Pengembangan Model Pembelajaran Adaptive Berdasarkan Teori Kecerdasan Majemuk. JSHP (Jurnal Sosial Humaniora dan Pendidikan), 2(1), 69-76.

Sabirin, M. (2014). Representasi dalam Pembelajaran Matematika. Jurnal Pendidikan Matematika, 1(2), 33-44.

Sinaga, G. F. M., \& Hartoyo, A. (2016). Kemampuan Representasi Matematis Siswa Ditinjau dari Gaya Belajar pada Materi Fungsi Kuadrat di SMA. Jurnal Pendidikan dan Pembelajaran, 5(06),1-12.

Yahaya, A., Karim, S. A., Yahaya, N., Pemasaran, J. P., Perniagaan, F. P., \& Segamat, C. (2003). Hubungan Gaya Pembelajaran Dengan Pencapaian Akademik Pelajar Di Tingkatan Empat Sekolah Menengah Teknik N. Sembilan. In National Seminar Memperkasakan Sistem Pendidikan, Puteri Pan-Pacific, Johore Bahru.

Basir, M. A., \& Maharani, H. R. (2016, May). Reasoning Ability Students in Mathematics Problems Solving Viewed from Cognitive Style. Prosiding In THE 2ND INTERNATIONAL SEMINAR ON EDUCATIONAL TECHNOLOGY 2016 (p. 99-102) 